\title{
'Solitary' necrotic nodules of the liver: an aetiology reaffirmed
}

\author{
M Sundaresan, B Lyons, A B Akosa
}

Department of

Histopathology

Hammersmith Hospital,

London

M Sundaresan

A B Akosa

Departments of

Histopathology,

Addenbrooke's Hospital,

Cambridge

B Lyons

Correspondence to:

Correspondence to:
Dr A B Akosa, Department of

DrA B Akosa, Department of
Histopathology, Whipps Cross Hospital, Leytonstone,

Accepted for publication 31 December 1990 London Ell INR.

\begin{abstract}
Morphological features of lesions conforming to the description of solitary necrotic nodules of the liver were compared with liver haemangiomata and necrotic tumour metastases in the liver. An origin in haemangiomata is confirmed for most of the lesions studied, although the necrotic nodule may represent the end stage of a variety of lesions. These lesions are usually benign, although necrotic nodules are often mistaken for liver metastases. A reticulin stain is useful in assessing the lesions.
\end{abstract}

'Solitary' necrotic nodules of the liver are rare lesions that have often been diagnosed as necrotic liver metastases on ultrasound examination. ${ }^{1}$ Macroscopically, they are firm lesions with a homogenous necrotic centre surrounded by a fibrotic capsule. Histologically, the capsule surrounds amorphous necrotic debris. In many lesions, feeding vessels are seen within the collar. Two of the cases described in the published reports had remnants of a structure resembling a haemangioma at their peripheries and it has been suggested that necrotic nodules arise within sclerotic haemangiomata. ${ }^{2}$

\begin{tabular}{|c|c|c|c|c|c|}
\hline $\begin{array}{l}\text { Case } \\
\text { no }\end{array}$ & $\begin{array}{l}\text { Age } \\
\text { (yrs) }\end{array}$ & Sex & Clinical details & $\begin{array}{l}\text { No of } \\
\text { lesions }\end{array}$ & $\begin{array}{l}\text { Size of } \\
\text { lesions } \\
(\mathrm{cm})\end{array}$ \\
\hline 1 & 27 & $M$ & $\begin{array}{l}\text { Teratoma of testis } \\
\text { lesion on anterior } \\
\text { border of liver }\end{array}$ & 3 & $\begin{array}{l}1.5 \\
1.6 \\
1.5\end{array}$ \\
\hline 2 & 63 & $\mathbf{M}$ & $\begin{array}{l}\text { Died of ruptured aortic } \\
\text { aneurysm. } \\
\text { Lesions on anterior } \\
\text { border of liver. } \\
\text { Cancer of prostate. } \\
\text { Past orchidectomy. }\end{array}$ & 3 & $\begin{array}{l}0.9 \\
0.6 \\
0.2\end{array}$ \\
\hline 3 & 36 & $\mathbf{F}$ & $\begin{array}{l}\text { Incidental finding at } \\
\text { cholecystectomy. } \\
\text { Multiple lesions along } \\
\text { anterior border. } \\
\text { On contraceptive pill. } \\
\text { Thyrotoxicosis }\end{array}$ & $\begin{array}{l}>20 \text { (only } \\
\text { one } \\
\text { sampled) }\end{array}$ & $\begin{array}{l}(0.2-0.4) \\
0.2\end{array}$ \\
\hline
\end{tabular}

TABLE II Summary of clinical information on 10 necropsy cases of cavernous haemangiomas of the liver

\begin{tabular}{|c|c|c|c|c|c|c|}
\hline $\begin{array}{l}\text { Case } \\
\text { no }\end{array}$ & $\begin{array}{l}\text { Age } \\
\text { (yrs) }\end{array}$ & Sex & $\begin{array}{l}\text { Size } \\
(\mathrm{cm})\end{array}$ & $\begin{array}{l}\text { No of } \\
\text { lesions }\end{array}$ & Positions & Cause of death \\
\hline 1 & 50 & $\mathbf{M}$ & 0.8 & 1 & Subcapsular anterior border & Lung cancer. Widespread \\
\hline $\begin{array}{r}2 \\
3 \\
4 \\
5 \\
6 \\
7 \\
8 \\
9 \\
9 \\
10\end{array}$ & $\begin{array}{l}43 \\
71 \\
84 \\
62 \\
70 \\
44 \\
88 \\
62 \\
72\end{array}$ & $\begin{array}{l}\mathbf{F} \\
\mathbf{M} \\
\mathbf{F} \\
\mathbf{M} \\
\mathbf{M} \\
\mathrm{F} \\
\mathbf{M} \\
\mathbf{M} \\
\mathrm{F}\end{array}$ & $\begin{array}{l}2 \cdot 0 \\
1 \cdot 3 \\
1 \cdot 5 \\
2 \cdot 0 \\
2 \cdot 5 \\
1 \cdot 8 \\
2 \cdot 0 \\
1 \cdot 2 \\
\text { Unknown }\end{array}$ & $\begin{array}{l}1 \\
1 \\
2^{\star} \\
2^{\star} \\
1 \\
1 \\
1 \\
3^{\star} \\
1\end{array}$ & $\begin{array}{l}\text { Subcapsular anterior border } \\
\text { Not stated } \\
\text { Not stated } \\
\text { Not stated } \\
\text { Subcapsular anterior border } \\
\text { Subcapsular anterior border } \\
\text { Subcapsuilar anterior border } \\
\text { Subcapsular anterior border } \\
\text { Not stated }\end{array}$ & $\begin{array}{l}\text { metastases including liver } \\
\text { Systemic sclerosis } \\
\text { Ruptured aortic aneurysm } \\
\text { Ruptured diverticulum } \\
\text { Septicaemia } \\
\text { Ischaemic heart disease } \\
\text { Metastatic cholangiocarcinoma } \\
\text { Adenocarcinoma of prostate } \\
\text { Ruptured aortic aneurysm } \\
\text { Ischaemic heart disease }\end{array}$ \\
\hline
\end{tabular}

$\star$ Only one lesion sampled.
TABLE III Summary of the clinical features of the patients with metastases

\begin{tabular}{|c|c|c|c|c|}
\hline $\begin{array}{l}\text { Case } \\
\text { no }\end{array}$ & $\begin{array}{l}\text { Age } \\
\text { (yrs)/ } \\
\text { sex }\end{array}$ & History & Necropsy findings & $\begin{array}{l}\text { Size of } \\
\text { metastasis } \\
\text { sampled } \\
(\mathrm{cm})\end{array}$ \\
\hline 1 & $60 M$ & $\begin{array}{l}\text { Oat cell carcinoma } \\
\text { of lung }\end{array}$ & $\begin{array}{l}\text { Multiple liver } \\
\text { metastases }\end{array}$ & $2-3$ \\
\hline 2 & $30 M$ & $\begin{array}{l}\text { Teratoma of testis. } \\
\text { Chemotherapy } \\
\text { treatment }\end{array}$ & $\begin{array}{l}\text { Retroperitoneal and } \\
\text { multiple liver } \\
\text { metastases }\end{array}$ & $1 \cdot 5$ \\
\hline 3 & $25 M$ & Teratoma of testis & $\begin{array}{l}\text { Multiple liver } \\
\text { metastases }\end{array}$ & 2 \\
\hline
\end{tabular}

We compared seven lesions from three patients conforming to the histological description of necrotic nodules of the liver with 10 liver haemangiomata found at necropsy and three necrotic tumour metastases. Similarities and dissimilarities between the three groups of lesions were compared.

\section{Methods}

Seven lesions from three patients from the surgical and necropsy files of the Hammersmith Hospital, London, and Addenbrooke's Hospital, Cambridge, were obtained, all had features of 'solitary' necrotic nodules of the liver. Multiple sections of all lesions were stained with haemotoxylin and eosin (H\&E), elastic van Gieson (EVG), and reticulin stains.

Immunohistochemical stains using the unlabelled (PAP) method to CAM 5.2, $\alpha$ fetoprotein, and $\beta$ human chorionic gonadotrophin ( $\beta$ HCG) were performed on case 1 . The clinical details of the three patients are summarised in Table I.

Sections of 10 liver haemangiomata obtained from necropsy material were stained with $H \& E$, EVG, and Martius scarlet blue stains to assess the degree of fibrosis, thrombosis with or without necrosis, and iron content. Clinical details of the haemangiomata are summarised in Table II.

Sections of three necrotic liver metastases, two from patients with known metastatic teratoma and one from a patient with metastatic oat cell carcinoma, were also stained with H\&E, EVG, and reticulin stains. Clinical details of the patients with metastases are summarised in Table III.

The following features were compared in each group:

Macroscopic site;

Microscopic site;

Presence of surrounding connective tissue collar;

Presence of feeding vessels at the edge of the lesion;

Presence of residual harmangioma like structure in collar;

Reticulin pattern within the necrosis. 


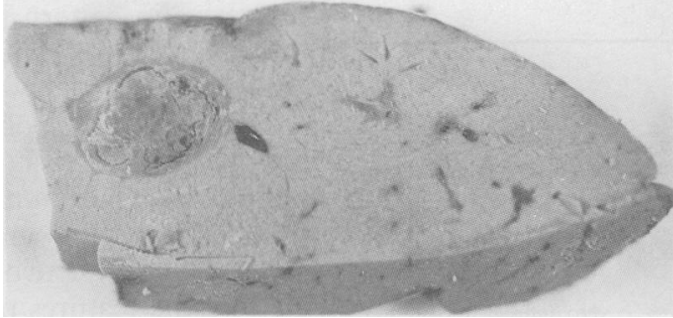

Figure 1: Macroscopic appearance of a solitary necrotic nodule showing the amorphous central debris surrounded by a capsule.

\section{Results}

All the cases of haemangiomata in which the macroscopic site of the lesion was stated (six of 10) were situated along the anterior surface of the liver. The seven necrotic nodules in this study were all found in similar positions. The necrotic nodules (Fig 1) were multiple in all three of our cases. Three of 10 of the haemangiomata were also multiple; case 9, with three lesions, had all three situated along the anterior border of the liver. The haemangiomata occurred adjacent to portal tracts, whereas the metastases had a more random distribution. All the necrotic nodules in cases 1 and 2 showed a feeding vessel consisting of a muscular artery within their collars (Fig 2). None of the lesions were cystic and no parasitic fragments or calcification were seen.

Reticulin stains on the necrotic nodules showed focal areas of preserved haemangiomatous pattern in the collars of six of seven cases (Fig 3A). A predominantly collapsed reticulin pattern with areas of ectatic vascular spaces were seen within the central necrosis (Fig 3B). In one of the three lesions in case 2 , the reticulin pattern was inconclusive. Case 3 showed an unusual reticulin pattern that strongly resembled the liver sinusoidal pattern seen adjacent to the capsule (Fig 3C). The liver cell plates were thicker within this lesion than in the surrounding liver. The comparative features of the three categories of lesions are summarised in Table IV. Immunohistochemical stains performed on case 1 were all negative.

\section{Discussion}

Six of the seven necrotic nodules in this study shared more in common with haemangiomata

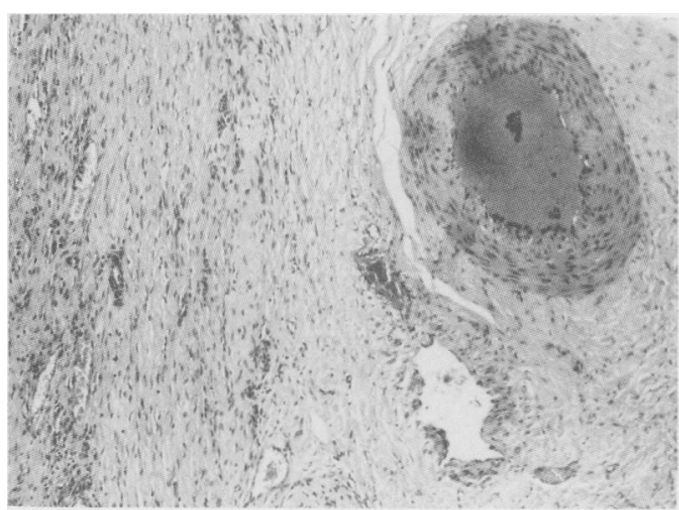

Figure 2: Capsule of a necrotic nodule showing a feeding vessel, which is a muscular artery, within the sclerotic collar of the lesion. (Original magnification $\times 400$.)

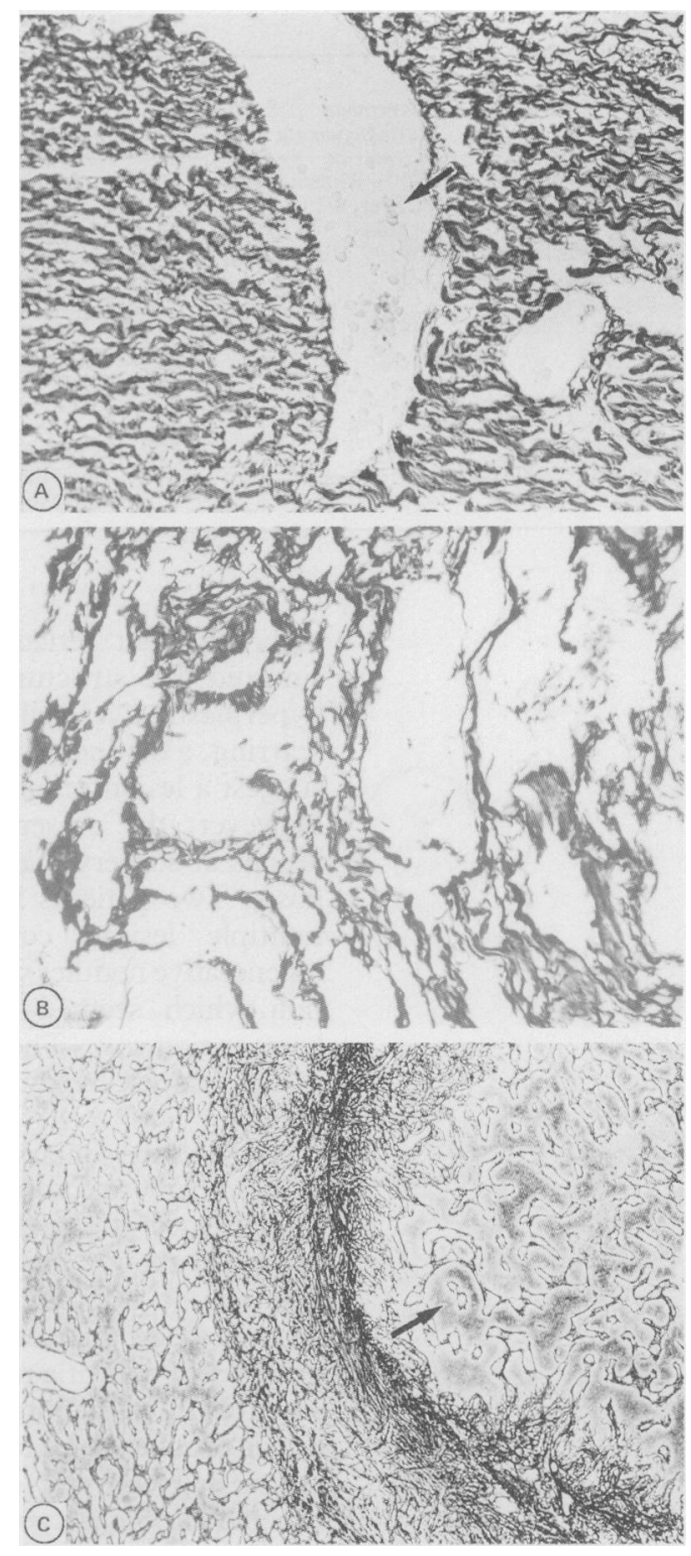

Figure 3: (A) Reticulin stain showing haemangioma like remnants at the periphery of the lesion. Ghost red blood cells (arrow) are seen in a vascular space. (Original magnification $\times 400$.

(B) The high power photomicrograph of the reticulin stain highlights the ectatic vascular spaces within the necrotic nodule. (Original magnification $\times 600$.)

(C) Reticulin pattern of lesion in case 3 showing hyperplastic liver structure (arrow) contrasted with pattern of liver outside the capsule. (Original magnification $\times 250$.)

than with metastases. The macroscopic and microscopic sites, the presence of a surrounding connective tissue collar, and feeding vessels at the edges of the lesion were similar to the former lesions, as described by Berry 1985. There has been recent controversy regarding the feeding vessels described in Berry's lesions. In our cases we accepted vessels in the nodule collars as feeding vessels when they were muscular arteries that were larger than the surrounding vessels within the portal tract.

All the lesions described in the published reports, ${ }^{12}$ as in our cases, were on the anterior surface of the liver.

Residual haemangiomatous structures in the collar were noted in the necrotic nodules and the reticulin pattern within the necrosis also showed a haemangiomatous pattern. In addition, we have described one lesion in case 3 with a strik- 
TABLE IV Comparison of characteristics of haemangiomata, necrotic nodules, and necrotic metastases

\begin{tabular}{|c|c|c|c|}
\hline & $\begin{array}{l}\text { Cavernous } \\
\text { haemangiomata }\end{array}$ & Necrotic nodules & Necrotic metatases \\
\hline Macroscopic site & $\begin{array}{l}\text { 6/10 - Anterior border } \\
\text { liver, } 4 / 10-\text { not } \\
\text { stated }\end{array}$ & $\begin{array}{l}7 / 7 \text { - Anterior border } \\
\text { liver }\end{array}$ & 3/3 Random distribution \\
\hline $\begin{array}{l}\text { Microscopic site } \\
\text { Presence of connective } \\
\text { tissue collare }\end{array}$ & $\begin{array}{l}10 / 10 \text { - portal tracts } \\
6 / 10\end{array}$ & $\begin{array}{l}6 / 7 \text { - Portal tracts } \\
7 / 7\end{array}$ & $\begin{array}{l}\text { 3/3 Random distribution } \\
0 / 3\end{array}$ \\
\hline $\begin{array}{l}\text { Presence of feeding } \\
\text { vessels }\end{array}$ & $10 / 10$ & $5 / 7$ & $\begin{array}{l}\text { No definite feeding } \\
\text { vessels }\end{array}$ \\
\hline $\begin{array}{l}\text { Residual } \\
\text { haemangioma } \\
\text { structure in collar }\end{array}$ & - & Present in 6/7 & Absent in $3 / 3$ \\
\hline $\begin{array}{l}\text { Reticulin pattern } \\
\text { within necrotic area }\end{array}$ & - & $\begin{array}{l}\text { 5/7- Haemangioma like, } \\
1 / 7 \text { - liver like, } 1 / 7- \\
\text { inconclusive }\end{array}$ & Tumour pattern \\
\hline
\end{tabular}

ingly different reticulin pattern. The hepatic sinusoid like structure within this lesion with hyperplastic liver cell plates, absence of central scarring, a distinct capsule, and a feeding vessel suggest a lesion resembling a hepatic adenoma. However, the presence of about 20 of these lesions at surgery may cast doubt on this diagnosis. Two patients have been described with multiple lesions composed of hyperplastic regenerative nodules with focal sinusoidal dilatation which seemed to arise from cavernous haemangiomas. ${ }^{3}$ The multiple hyperplastic nodules in case 3 may represent a similar phenomenon.

Seventy five solitary lesions were found in the liver in 1500 necropsies, five of which were 'solitary necrotic nodules. ${ }^{.4}$ None of the cases described showed cystic spaces, parasites, or an eosinophilic infiltrate. In contrast, in another series of cases, three of four had cystic spaces and evidence of parasitic material was found in two. ${ }^{5}$ The fourth case contained calcified amorphous debris thought to be of parasitic origin. Another report describes a $1 \mathrm{~cm}$ nodule of the liver in which Enterobius vermicularis was seen in the centre. $^{6}$ All lesions were noted to be within the capsule but the specific sites were not described. In one case the lesion was described as being close to the gall bladder, indicating a posterior site. Although no comment was made regarding the reticulin pattern in these cases, it would be unusual to find a reticulin pattern in nodules of parasitic origin.

In recent correspondence between Berry and Shepherd, ${ }^{7}$ it was suggested that necrotic nodules may have multiple aetiologies including haemangiomatous and parasitic origins. We suggest that these two entities may be differentiated by the features mentioned above - that is, absence of cystic spaces, parasitic material, calcification, or a reticulin pattern. All our cases had features consistent with, or related to, a haemangiomatous origin.

The lesion known as 'solitary' necrotic nodule of the liver can be multiple and can occur in patients without evidence of malignant disease. We would reiterate that these lesions may often be mistaken for metastases, the more so when they are multiple.

We conclude that necrotic nodules, in a large number of cases, may represent the end stage of a variety of lesions, but a large proportion of these are degenerate haemangiomata. We could not, however, show thrombosis in any of the feeding vessels as a cause for the complete necrosis of these lesions.

Part of the data in this study was presented as a poster at the Pathological Society in January 1990

We are grateful to Dr Richard Ball of Addenbrooke's Hospital, Cambridge, for presenting us with the material for case 2, to the laboratory staff of the Hammersmith Hospital for technical assistance, and to Bill Batchelor for photographic work. We are also grateful to Dr C S Foster for reading this manuscript and offering constructive criticism.

1 Shepherd NA, Lee G. Solitary necrotic nodules of the liver simulating hepatic metastases. 7 Clin Pathol 1983; 36: 1181-3.

2 Berry CJ. Solitary necrotic nodules of the liver: a probable pathogenesis. F Clin Pathol 1985; 38: 1278-80.

3 Ndimbie OK, Goodman ZD, Chase RL, et al. Haemangiomas with localized nodular proliferation of the liver: a suggestion on the pathogenesis of focal nodular hyperplasia. Am $\mathcal{F}$ Surg Pathol 1990; 14: 142-50.

4 Berry CJ. Liver lesions in an autopsy population. Hum Toxico 1987; 6: 209-14.

Drury RAB. Larval granulomata in the liver. Gut 1962; 3: 289-

6 Mondou EN, Gnepp DR. Hepatic granulomas in the live resulting from Enterobius vermicularis. Am $\mathcal{F}$ Clin Pathol 1989; 91: $97-100$

7 Berry CJ, Shepherd NA. Solitary necrotic nodule of the liver. J Clin Pathol 1990; 43: 348-9. 